\title{
Low Levels of High-density Lipoprotein in Patients with Pediatric Cancer at Diagnosis
}

https://doi.org/10.32635/2176-9745.RBC.2019v65n3.528

Baixos Níveis de Lipoproteínas de Alta Densidade em Pacientes com Câncer Infantojuvenil ao Diagnóstico
Bajos Niveles de Lipoproteínas de Alta Densidade en Pacientes con Cáncer Juvenil en el Momento del Diagnóstico

Adriana Garófolo'; Priscila dos Santos Maia-Lemos²

\begin{abstract}
Introduction: Cancer patients have metabolic imbalances due to the disease, treatment and their complications. Increases in triglycerides and glucose profile and catabolism of protein have been described and are associated with inflammatory response as result of the tumor activity or necrosis. Objective: To evaluate the blood lipid, lipoproteins, glucose and albumin levels in pediatric cancer patients at diagnosis. Method: Observational cross-sectional study. The inclusion criteria were children and adolescents with newly diagnosed malignancies and blood analysis results. The exclusion criteria were: previous anticancer therapy or surgical treatment, blood sample not collected and patients who refused to participate in the study. Results: It were evaluated 81 children and adolescents with newly diagnosed malignancies. There was decrease of $56 \%$ and $41 \%$ of high-density lipoprotein cholesterol (HDL-C) and triglycerides (TG), $14 \%$ and $10 \%$ of albumin and glucose, and 10\% and 7.6\% of total cholesterol (TC) and low-density lipoprotein cholesterol (LDL-C), respectively, for the patients. HDL-C showed statistical differences between solid and hematological cancer patients $(\mathrm{p}<0.05)$. The means and medians of albumin, glucose, HDL-C and TG demonstrated that hematological patients are more prone to metabolic disturbances. HDL-C in this group was $24 \pm 12$ versus $40 \pm 15 \mathrm{mg} / \mathrm{dl}$ in other cancers. Conclusion: The primary result found in the present study was in HDL-C, mainly in patients with hematological and metastatic cancer. These disturbances could be associated with cancer-related acute inflammatory response. Key words: Triglycerides/blood; Cholesterol, HDL/blood; Blood Glucose; Serum Albumin; Neoplasms.
\end{abstract}

\section{Resumo}

Introduçáo: Pacientes com câncer apresentam desequilíbrios metabólicos em virtude da doença, do tratamento e de suas complicaçóes. Alteraçóes nos triglicerídeos, perfil de glicose e catabolismo de proteínas foram descritas e estão associadas à resposta inflamatória por conta da atividade tumoral ou necrose. Objetivo: Avaliar os níveis de lipídios no sangue, lipoproteínas, glicose e albumina em pacientes com câncer infantojuvenil no momento do diagnóstico. Método: Estudo observacional transversal. Os critérios de inclusẫo foram crianças e adolescentes com neoplasias recém-diagnosticadas e resultados de exame de sangue; e os critérios de exclusão, terapia anticâncer ou tratamento cirúrgico prévio, amostra de sangue não coletada e pacientes que se recusaram a participar do estudo. Resultados: Foram avaliadas 81 crianças e adolescentes com neoplasias recém-diagnosticadas. Houve decréscimo de $56 \%$ e $41 \%$ para lipoproteína de alta densidade-colesterol (HDL-C) e triglicerídeos (TG), 14\% e 10\% para albumina e glicose e $10 \%$ e $7,6 \%$ para colesterol total (CT) e colesterol de lipoproteína de baixa densidade (LDL-C), respectivamente. O HDL-C mostrou diferenças estatísticas entre pacientes com câncer sólido e hematológico $(\mathrm{p}<0,05)$. As médias e medianas de albumina, glicose, HDL-C e TG demonstraram que pacientes com tumores hematológicos são mais propensos a distúrbios metabólicos. O HDL-C neste grupo foi de $24 \pm 12$ versus $40 \pm 15 \mathrm{mg} /$ $\mathrm{dl}$ em outros cânceres. Conclusáo: A principal alteração encontrada no presente estudo foi no HDL-C, principalmente em pacientes com câncer hematológico e metastático. Essas alteraçóes podem estar associadas à resposta inflamatória aguda relacionada ao câncer.

Palavras-chave: Triglicerídeos/sangue; HDL-Colesterol/sangue; Glicemia; Albumina Sérica; Neoplasias.

\section{Resumen}

Introducciòn: Los pacientes con cáncer tienen desequilibrios metabólicos debido a la enfermedad, el tratamiento y sus complicaciones. Los cambios en los triglicéridos y el perfil de glucosa y el catabolismo de las proteínas se han descrito y están asociados con la respuesta inflamatoria debido a la actividad tumoral o la necrosis. Objetivo: Evaluar los niveles de lípidos, lipoproteínas, glucosa y albúmina en sangre en pacientes con cáncer juvenil en el diagnóstico. Método: Estudio transversal observacional. El criterio de inclusión fue niños y adolescentes con neoplasias recién diagnosticadas con análisis de sangre realizado. Criterios de exclusión: terapia anticancerígena previa o tratamiento quirúrgico, muestra de sangre no realizada y pacientes que se negaron a participar en el estudio del protocolo. Resultados: Se evaluaron 81 niños y adolescentes con neoplasias recién diagnosticadas. Se observó un cambio en $56 \%$ y $41 \%$ para el colesterol de lipoproteínas de alta densidad (HDL-C) y triglicéridos (TG), 14\% y 10\% para albúmina y glucosa, y $10 \%$ y 7,6\% para colesterol total (TC) y colesterol de lipoproteínas de baja densidad (LDL-C), respectivamente. HDL-C mostró diferencias entre pacientes con cáncer sólido y hematológico $(\mathrm{p}<0.05)$. Las medias y medianas de albúmina, glucosa, HDL-C y TG demostraron que el grupo hematológico tienden a alteraciones metabólicas más importantes. El HDL-C en este grupo fue de $24 \pm 12$ versus $40 \pm 15 \mathrm{mg} / \mathrm{dl}$ en otros tipos de cáncer. Conclusión: El cambio primario encontrado en el presente estudio fue en HDL-C, principalmente en pacientes con cáncer hematológico y metastásico. Estos cambios podrían estar asociados con la respuesta inflamatoria aguda relacionada con el cáncer.

Palabras clave: Triglicéridos/sangre; HDL-Colesterol/sangre; Glucemia; Albúmina Sérica; Neoplasias.

\footnotetext{
1 Universidade Federal de São Paulo (Unifesp). Instituto de Oncologia Pediátrica do Grupo de Apoio ao Adolescente e à Criança com Câncer da Unifesp. São Paulo (SP), Brazil. Orcid iD: https://orcid.org/0000-0001-7703-7088

2 Unifesp. Instituto de Oncologia Pediátrica do Grupo de Apoio ao Adolescente e à Criança com Câncer da Unifesp. São Paulo (SP), Brazil. Orcid iD: https://orcid. org/0000-0002-5859-8493

Address for correspondence: Adriana Garófolo. Rua Manoel da Nóbrega, 1088 - apto. 131. Paraíso. São Paulo (SP), Brazil. CEP 04001-000. E-mail: adrianagarofolo@graacc.org.br
} 


\section{INTRODUCTION}

Cancer patients may present metabolic unbalances because of the disease, the treatment and their complications. Increases in lipid, lipoprotein and glucose profile and catabolism of protein have been described in these patients and are associated with inflammatory response due to the presence of the tumor, infectious or anticancer therapy complications. This condition has been described as anorexia-cachexia syndrome ${ }^{1,2}$, which is generated by elevated pro-inflammatory cytokines levels $s^{3-5}$. It is believed that inflammatory response is an important factor in the inter individual variability of response and toxic effects of cancer chemotherapy ${ }^{6}$.

Low HDL-C and high glucose and triglycerides levels were reported in children with leukemia and lymphoma and other forms of widespread malignant disease ${ }^{7-10}$. High triglycerides and glucose levels, for example, are deleterious to the immune system, increasing the risk of infection; low clearance of triglycerides leads to a partial blockage of both macrophage and granulocyte function, increasing the risk of infectious complications and morbidity ${ }^{11-16}$. Lipids and glucose intolerance impair oxidation and incorporation of the nutrients during inflammatory response ${ }^{14-16}$.

All these alterations have been documented in the international literature, but have never been reported in Brazilian pediatric cancer patients. Therefore, the impact of these factors in Brazilian patients is still unknown, since genetic and dietary profiles may play a role in the aforementioned alterations.

The importance of this study is to identify those abnormalities in different groups of Brazilian patients with cancer, in order to propose studies about prognosis and immunomodulation in the future. To that end, the aim of the study was to evaluate the blood lipid, lipoproteins, glucose and albumin levels in pediatric cancer patients at diagnosis.

\section{METHOD}

This is an observational cross-sectional study conducted at the Pediatric Oncology Institute (IOP) of the Federal University of São Paulo (UNIFESP-EPM) with patients who presented newly diagnosed malignancies. All the patients with previous anticancer treatment or history of corticosteroid use were excluded from this analysis.

Blood samples were collected after an overnight fast (8 hours) at the enrollment day, in ethylenediaminetetraacetic acid (EDTA) or heparin anticoagulating tubes to be immediately centrifuged. Total plasma cholesterol $(\mathrm{CH})$ was measured by calorimetric method (HDL cholesterol enzymatic, K015, Bioclin, Belgium). Total Cholesterol Assay Kit measures the total cholesterol within serum, plasma, lysate, or tissue samples. The assay is based on the enzyme driven reaction that quantifies both cholesterol esters and free cholesterol. Cholesterol esters are hydrolyzed via cholesterol esterase into cholesterol, which is then oxidized by cholesterol oxidase into the ketone cholest-4-en-3-one plus hydrogen peroxide. Then, the hydrogen peroxide is detected with a highly specific colorimetric probe. Horseradish peroxidase catalyzes the reaction between the probe and hydrogen peroxide, which bind in a 1:1 ratio. Samples are compared to a known concentration of cholesterol standard in a 96well microtiter plate format. Samples and standards are incubated for 45 minutes and then read with a standard 96-well colorimetric plate reader.

HDL-C determination was performed by calorimetricenzymatic method (HDL cholesterol enzymatic, K015, Bioclin, Belgium). It is measured in serum or plasma after selective precipitation of LDL and VLDL. In a centrifuge tube pipette $250 \mu \mathrm{L}$ of the sample and 250 $\mu \mathrm{L}$ of the precipitate, shaken strongly for 30 seconds, centrifuged at $3500 \mathrm{rpm}$ for 15 minutes to obtain a clear supernatant, pipette the clear supernatant immediately after centrifugation, taking care to not resuspend the precipitate to avoid falsely high results. Colorimetry: identify the test tubes and pipette, homogenize and incubate in a water bath at $37^{\circ} \mathrm{C}$ for 10 minutes. The water bath level should be above the level of the reagents in the tubes, make the photometric readings of the Standard $(\mathrm{AP})$ and the Test (AT) at $500 \mathrm{~nm}$, resetting the device to White. The color is stable for 60 minutes.

Plasma triglycerides (TG) were enzymatically measured. Serum was separated up to 2 hours after collection and stored under refrigeration at 2 to $8^{\circ} \mathrm{C}$, to maintain stability for 72 hours. The temperature of the water bath or thermostat was adjusted to $37^{\circ} \mathrm{C}$. The temperature remained constant during the test. Homogenization and immediately incubation for 5 minutes at $37^{\circ} \mathrm{C}$. The absorbance was read within 60 minutes against the white reagent. For calculations: triglycerides $(\mathrm{mg} / \mathrm{dL})=$ Sample Absorbance X Standard Concentration / Standard Absorbance. Calibration Factor $(\mathrm{Fc})=$ Standard Concentration $(\mathrm{mg} /$ $\mathrm{dL}) /$ Standard Absorbance. Triglycerides $(\mathrm{mg} / \mathrm{dL})=$ Sample Absorbance x Fc).

The Friedewald et al. ${ }^{17}$ equation was applied to calculate low-density lipoprotein cholesterol (LDL-C) from $\mathrm{CH}$, TG, and HDL-C Glucose Hexokinase II determined blood glucose. It is an enzymatic method that uses the enzymes hexokinase and glucose-6-phosphate dehydrogenase. Glucose is phosphorylated by ATP in the presence of hexokinase. The glucose-6-P is oxidized in the 
presence of glucose- 6 phosphate dehydrogenase, resulting in the reduction of NAD to NADH, whose absorbance is measured. GLUH applied to biochemical systems of Advia is a reagent containing two components, reagent 1 (R1) and reagent 2 (R2). The blood sample is added to the R1, which contains buffer, ATP and NAD. The absorbance readings of the sample in $\mathrm{R} 1$ are obtained and used to correct the interfering substances in the sample. Then, $\mathrm{R} 2$ is added, initiating the conversion of glucose and the development of absorbance at $340 / 410 \mathrm{~nm}$. The difference between the absorbance at R1 and R2 is proportional to the glucose concentration.

Turbidimetrical method was used to measure serum albumin. This method is based on the dispersion of suspended particles. When a collimated beam of light reaches a suspended particle, portions of the light are absorbed, reflected or dispersed by the solution. The amount of light transmitted in the front direction is detected. The amount of light absorbed by a suspension of particles depends on the concentration and size of the particles. Solutions that require quantification by turbidimetric methods are carried out by means of photometers or spectrophotometers of visible region.

Reference of lipids was based on the "Guidelines of the National Cholesterol Education Program"18. When albumin and glucose were below $3.5 \mathrm{mg} / \mathrm{dl}$ and above 110 $\mathrm{mg} / \mathrm{dl}$, respectively, they were considered abnormal. It were also assessed the family history of hypertriglyceridemia and hypercholesterolemia.

Patients over 18 years old and the parents or guardians of patients below that aged signed an informed consent approved by the Institutional Review Board of UNIFESP, which reviewed and approved the study (number 0840/06).

\section{StATISTICAL ANALYSIS}

Descriptive data are expressed as means and standard deviation (SD) or median (minimum e maximum) in case of skewed distributions, and as frequencies and percentages or ranges.

The Chi-square test was adopted to compare the rate of abnormalities between hematological versus solid and metastatic versus non-metastatic cancers. T test or Mann' Whitney were used to compare means or medians for hematological versus solid and metastatic versus nonmetastatic cancer, depending on the normality of the sample. A p-value below 5\% was statistically significant.

\section{RESULTS}

Eighty-one patients were included: twenty-one with hematological and sixty-four with solid cancers. The median age was 8.7 years (range, 0.2 - 21.9 years). Serum TG, CH and HDL-C were evaluated in 81 patients, whereas serum albumin, glucose and LDL-C in 73, 77 and 79, respectively. Table 1 shows the demographic characteristics.

Table 1. Demographic characteristics of pediatric and adolescent cancer patients $(n=81)$

\begin{tabular}{lcc}
\hline \multicolumn{1}{c}{ Characteristic } & $\begin{array}{c}\text { Median } \\
\text { (year) }\end{array}$ & Range \\
\hline Age & 8.7 & $(0.2-21.9)$ \\
Gender & $\begin{array}{c}\text { Number } \\
\text { Male }\end{array}$ & $\begin{array}{c}\text { Percentage } \\
\text { Female }\end{array}$ \\
Diagnostics & 29 & 64 \\
ALLa & 12 & 36 \\
AMLb & 4 & 15 \\
Biphenotipic leukemia & 1 & 5 \\
NHLc & 2 & 1 \\
HLd & 2 & 2.5 \\
CNSe & 18 & 2.5 \\
Neuroblastoma & 2 & 2.5 \\
Wilms tumor & 2 & 2.5 \\
Bone tumors & 14 & 17 \\
Rabdomyosarcoma & 2 & 2.5 \\
Germ cells tumor & 4 & 5 \\
Carcinomas & 4 & 5 \\
Retinoblastoma & 8 & 10 \\
Others & 6 & 7.5 \\
\hline
\end{tabular}

${ }^{a}$ ALL: acute lymphoblastic leukemia; ${ }^{\mathrm{A}} \mathrm{AML}$ : acute myeloid leukemia; ${ }^{\mathrm{N} H L}$ : non-Hodgkin lymphoma; ${ }^{d} \mathrm{HL}$ : Hodgkin lymphoma; ${ }^{\mathrm{c}} \mathrm{CNS}$ : central nervous system (craniofaringioma, astrocitoma, ependimoma, Medulloblastoma, pineal germ tumor).

Seventeen $(21 \%)$ of the patients had a family history of hypertriglyceridemia and/or hypercholesterolemia; two of them had solid tumor.

Forty-five out of $81(56 \%)$ and 10/73 (14\%) presented low levels of HDL-C and albumin, and 33/81 (41\%) and 8/77 (10\%) showed high levels of TG and glucose, respectively. CH was elevated in $8 / 81(10 \%)$ and LDL-C in $6 / 79(7.6 \%)$.

The abnormalities of HDL-C rates were statistically higher $(p=0.001)$ in the hematologic tumor when compared to the solid tumor patients. The percentage of patients with albumin and TG abnormalities were higher in the hematologic tumor group, although not reaching statistical significance (Figure 1).

The mean of HDL-C levels of patients with hematological tumors demonstrated to be lower than the solid tumors (Table 2).

The analysis for metastatic $(\mathrm{n}=27)$ versus nonmetastatic $(\mathrm{n}=54)$ cancer (Figure 2$)$ demonstrated higher incidence of abnormalities in the HDL-C and lower mean of the values (Table 3 ). 


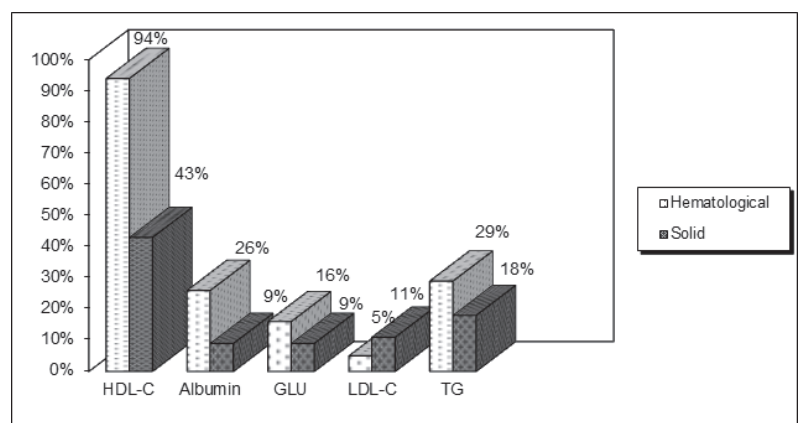

Figure 1. Percentage of patients with abnormalities in the biochemical data between hematological and solid cancers

a Significant difference between leukemia and other cancers with $\mathrm{p}=0.001 ; \mathrm{X} 2$ $=10.23(\mathrm{OR}=12.43: 2.65-58.18 ; 95 \% \mathrm{CI})$.

HDL-C = high-density lipoprotein cholesterol; GLU = glucose; LDL-C = lowdensity lipoprotein cholesterol; $\mathrm{TG}=$ triglycerides.

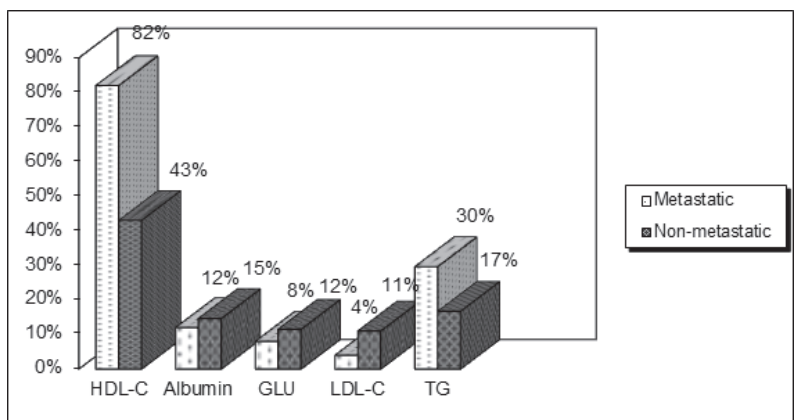

Figure 2. Percentage of patients with abnormalities in the biochemical data of metastatic $(n=27)$ and non-metastatic $(n=54)$ cancers

a Significant difference between metastatic and non-metastatic cancer; $\mathrm{p}=0.001$; $\mathrm{X} 2=9.87(\mathrm{OR}=5.93 ; 1.95-18)$

\section{DISCUSSION}

This study confirmed in Brazilian patients similar abnormalities observed in other studies ${ }^{5,7-9}$, mainly higher prevalence of HDL-C in hematological and metastatic cancer patients. Other studies also reported low HDL-C in patients with leukemia and lymphoma, corroborating our results. In one of these studies, abnormalities with other forms of widespread malignant disease were observed in children at diagnosis, but not in localized disease 7 . In our analysis with metastatic patients it was also demonstrated higher percentage of HDL abnormalities. Prevalence of metabolic alterations is, therefore, probably associated to the severity of the disease, when the body prioritizes protein synthesis due to the pro-inflammatory response caused by the most aggressive cancer disease. However, other mechanisms must be explored. On the other hand, glucose and albumin did not demonstrate an important decrease in the present study.

Iqbal et al. ${ }^{5}$ showed lower mean $\mathrm{CH}$, LDL-C, HDL-C and albumin in cancer in comparison to non-cancer patients; they were also significantly lower in those with metastatic solid tumors. They also found that TG was lower in non-metastatic disease and no association was observed between LDL-C, HDL-C and TG and the stage of disease ${ }^{5}$. In the current study, TG abnormalities were observed mainly in metastatic group, however without statistical differences in the prevalence rate. Possibly, the qualitative analysis (percentage of abnormalities) and the

Table 2. Blood lipid, glucose and albumin profile in patients with hematological $(n=21)$ versus solid cancers $(n=64)$

\begin{tabular}{lcccc}
\hline \multicolumn{1}{c}{ Serum/plasma } & Patients & Hematological & Solid & P value* \\
\hline Albumin $(\mathrm{g} / \mathrm{dl})$ & 73 & $3.8 \pm 0.7$ & $4.2 \pm 0,6$ & $\mathrm{NS}$ \\
Glucose $(\mathrm{mg} / \mathrm{dl})$ & 77 & $94 \pm 21$ & $89 \pm 25$ & $\mathrm{NS}$ \\
Cholesterol (mg/dl) & 81 & $135 \pm 33$ & $152 \pm 41$ & $\mathrm{NS}$ \\
HDL-C (mg/dl) & 81 & $24 \pm 12$ & $40 \pm 15$ & 0.001 \\
LDL-C (mg/dl) & 79 & $81 \pm 29$ & $92 \pm 29$ & $\mathrm{NS}$ \\
Triglycerides (mg/dl) & 81 & $147 \pm 105$ & $112 \pm 75$ & $\mathrm{NS}$ \\
Triglycerides (mg/dl) & 81 & $109(59-493)$ & $87(17-429)$ & $\mathrm{NS}$ \\
\hline
\end{tabular}

Values are expressed as mean \pm standard deviation, excepted for the values for triglycerides, which are also expressed as the range and the median. HDL-C $=$ highdensity lipoprotein cholesterol; LDL-C = low-density lipoprotein cholesterol. ${ }^{*}$ T test or Mann' Whitney test.

Table 3. Blood lipid, carbohydrate and albumin profile in patients with metastatic $(n=27)$ versus non-metastatic $(n=54)$ cancers

\begin{tabular}{lcccc}
\hline \multicolumn{1}{c}{ Serum/plasma } & Patients & Metastatic & Non-metastatic & P value* \\
\hline Albumin (g/dl) & 73 & $4.0 \pm 0.6$ & $4.2 \pm 0,7$ & NS \\
Glucose (mg/dl) & 77 & $87 \pm 19$ & $91 \pm 26$ & NS \\
Cholesterol (mg/dl) & 81 & $140 \pm 33$ & $151 \pm 42$ & NS \\
HDL-C (mg/dl) & 81 & $29 \pm 12$ & $40 \pm 16$ & 0.002 \\
LDL-C (mg/dl) & 79 & $82 \pm 27$ & $93 \pm 30$ & NS \\
Triglycerides (mg/dl) & 81 & $149 \pm 111$ & $108 \pm 64$ & NS \\
Triglycerides (mg/dl) & 81 & $108(58-493)$ & $88(17-303)$ & NS \\
\hline
\end{tabular}

Values are expressed as mean \pm standard deviation, excepted for the values of triglycerides, which are also expressed as the range (minimum and maximum) and the median. HDL-C = high-density lipoprotein cholesterol; LDL-C = low-density lipoprotein cholesterol. *T test or Mann' Whitney test. 
heterogeneity of the diagnosis of the sample did not allow differences to be found.

Lower mean of HDL-C was found, comparing our patients with a study performed in healthy Brazilian children and adolescents ${ }^{19-21}$. Higher TG and lower LDL-C and $\mathrm{CH}$, also were encountered in children with hematological cancer and metastatic patients when compared to the Brazilian study ${ }^{21}$.

Malignant tumors are associated with synthesis of pro-inflammatory mediators - TNF-a, Interleukins 1 and 6 and others ${ }^{22,23}$. These cytokines stimulate acute inflammatory response, increasing positive and decreasing negative acute phase proteins synthesis. They cause metabolic disturbances such as higher fat utilization, glucose and lipid intolerance, leading to a catabolic status $^{2,24}$. HDL-C could be reduced due to cytokines action, acting as a negative acute phase protein.

These abnormalities are present in several conditions such as inflammation, infection and trauma ${ }^{25-28}$. Herishanu et al. ${ }^{29}$, demonstrated that elevated baseline C reactive protein levels are associated with shorter survival and development of second cancers in patients with chronic lymphoid leukemia ${ }^{29}$.

Albumin has been studied and high TG levels were observed in patients with blood or bone marrow invasion, suggesting a correlation with the turnover of the malignant proliferation $^{30}$.

Malignancy also seems to influence $\mathrm{CH}$ levels. Hypocholesterolemia has been observed in various forms of cancer at diagnosis, particularly in hematological ones $^{5,31}$. Low $\mathrm{CH}$ has been associated with increased mortality from cancer in several observational and clinical studies ${ }^{32}$.

Naik et al..$^{33}$ found that low $\mathrm{CH}$ and HDL-C together with hypertriglyceridemia were the most prominent features in pediatric patients with leukemia and Hodgkin's disease ${ }^{33}$.

Recently, two other studies about leukemia showed that these abnormalities are correlated with the disease activity, being reversed during remission ${ }^{34,35}$.

It were not observed any important abnormalities in $\mathrm{CH}$ and LDL-C, but apparently, the means values were slightly reduced in hematological and metastatic cancer.

Previous studies have demonstrated that cancer patients often present aberrant blood lipid profiles. Moreover, blood lipid levels of cancer patients have shown to be associated with pathogenesis and progression of cancer. High-density lipoprotein cholesterol has antiinflammatory properties.

This study has some limitations, for example, its crosssectional design, which does not allow causal analysis, the greater number of solid than hematological cancer, the absence of control group with healthy population, and the loss of some blood analyses. Future studies need to investigate subtypes of lipoprotein, tracking changes in values and analyze how they correlate with clinical outcomes. It was not possible to affirm that the present results found were related to inflammatory response because it were not measured CRP or other inflammatory marker.

Limited published studies have focused on pediatric cancer inflammation and its metabolic consequences. However, inflammation could be associated with a pre-cachexia status in a high percentage of patients at diagnosis, mainly in those with widespread metastatic disease. This condition leads to anorexia, weight loss, insulin resistance and increased destruction of muscle proteins and reduced functional capacity and quality of life $\mathrm{e}^{36-38}$, increasing morbidity and mortality in cancer patients $^{39}$. The presence of malignant tumor cells stimulates the host to produce cytokines and other pro-inflammatory mediators responsible for alterations in substrate metabolism. In some studies with cancer patients, albumin has been suggested as a prognostic factor and its alterations may be associated with other aspects, in addition to the inflammatory response ${ }^{40,41}$. This profile depends on the cancer diagnosis and stage/ severity of the disease ${ }^{36}$.

A recent study on the HDLs of young ALL survivors indicates an altered metabolism and a shift in their proteome affecting specifically their anti-thrombotic, antiapoptotic and anti-inflammatory capacities. These HDLs have an abnormal composition with a lower content of free and esterified cholesterol compared to controls. They also expressed some proteins not detectable in the control samples; most of them are either pro-thrombotic or proapoptotic. These findings may be relevant to the field of cancer survivorship in providing potential diagnostic, prognostic or therapeutic biomarkers of HDL-C functionality and metabolism in ALL ${ }^{42}$.

More studies are necessary to know the metabolic behavior of these components, comparing with healthy subjects, evaluating patients prospectively in different phases of treatment, and correlating with the disease, drugs, energy expenditure and nutritional condition. These abnormalities could be involved in the response to chemotherapy and in the mechanism of oncogenesis. Thus, it is important to elucidate that influence on the cancer prognostic ${ }^{29,34,35}$.

\section{CONCLUSION}

The primary result found in the present study was low HDL-C levels at diagnosis of cancer. Albumin and TG also 
presented abnormalities in cancer patients. Hematological and metastatic cancer demonstrated to influence these abnormalities more importantly. The prevalence of metabolic alterations is, therefore, probably associated to the spread and severity of the cancer, when the body prioritizes protein synthesis due to pro-inflammatory response caused by the most aggressive tumor.

\section{CONTRIBUTIONS}

Adriana Garófolo participated of the conception and design of the study, collection, analysis and interpretation of the study data, wording and critical review with intellectual contribution and approval of the final version for publication. Priscila dos Santos Maia-Lemos participated of the conception and design of the study, collection, analysis and interpretation of the study data and approval of the final version for publication.

\section{DECLARATION OF CONFLICT OF INTERESTS}

There are no conflict of interests to declare.

\section{FUNDING SOURCES}

None.

\section{REFERENCES}

1. Proctor MJ, Morrison DS, Talwar D, et al. A comparison of inflammation-based prognostic scores in patients with cancer. A Glasgow Inflammation Outcome Study. Eur J Cancer. 2011; 47(17):2633-41 doi: 10.1016/j. ejca.2011.03.028

2. Bauer J, Jürgens H, Frühwald MC. Important aspects of nutrition in children with cancer. Adv Nutr. 2011;2(2):67-77. doi: https://doi.org/10.3945/ an. 110.000141

3. Raguso CA, Dupertuis YM, Pichard C. The role of visceral proteins in the nutritional assessment of intensive care unit patients. Curr Opin Clin Nutr Metab Care. 2003;6(2):211-6. doi: http://dx.doi. org/10.1097/00075197-200303000-00010

4. Mainous AG, Wells BJ, Everett CJ, et al. Association of ferritin and lipids with C-reactive protein. Am J Cardiol. 2004;93(5):559-62. https://doi.org/10.1016/j. amjcard.2003.11.018

5. Iqbal A, Zaida M, Munir R, et al. Atypical plasma lipid profiles in leukemia. Clin Chim Acta. 2016;452:129-133 doi: https://doi.org/10.1016/j.cca.2015.11.003

6. Slaviero KA, Clarke SJ, Rivory LP. Inflammatory response: an unrecognised source of variability in the pharmacokinetics and pharmacodynamics of cancer chemotherapy. Lancet Oncol. 2003;4(4):224-32. doi: https://doi.org/10.1016/s1470-2045(03)01034-9

7. Halton JM, Nazir DJ, McQueen MJ, et al. Blood lipid profiles in children with acute lymphoblastic leukemia. Cancer. 1998;83(2):379-84. doi: https://doi.org/10.1002/ (SICI) 1097-0142(19980715) 83:2<379::AIDCNCR24>3.0.CO;2-P

8. Spiegel RJ, Schaefer EJ, Magrath IT, et al. Plasma lipid alterations in leukemia and lymphoma. Am J Med 1982;72(5):775-82. doi: https://doi.org/10.1016/00029343(82)90543-5

9. Blackman JD, Cabana VG, Mazzone T. The acutephase response and associated lipoprotein abnormalities accompanying lymphoma. J Intern Med. 1993;233(2):201-4. doi: https://doi.org/10.1111/j.1365-2796.1993.tb00674.x

10. Garófolo A, Modesto PC, Gordan LN, et al. Perfil de lipoproteínas, triglicérides e glicose plasmáticos de pacientes com câncer durante o transplante de medula óssea. Rev Nutr. 2006;19(2):281-8. doi: http://dx.doi. org/10.1590/S1415-52732006000200015

11. Nieman DC, Henson DA, Nehlsen-Cannarella SL, et al. Influence of obesity on immune function. J Am Diet Assoc. 1999;99(3):294-9. doi: http://dx.doi. org/10.1016/S0002-8223(99)00077-2

12. Hamawy K, Moldawer LL, Georgieff M, et al. The effect of lipid emulsions on reticuloendothelial system function in the injured animal. JPEN J Parenter Enteral Nutr1985;9(5):559-65. doi: http://dx.doi. org/10.1177/0148607185009005559

13. Seidner DL, Mascioli EA, Istfan NW, et al. Effects of long-chain triglyceride emulsions on reticuloendothelial system function in humans. JPEN J Parenter Enteral Nutr. 1989;13(6):614-9. doi: http://dx.doi. org/10.1177/0148607189013006614

14. Aksnes J, Eide TJ, Nordstrand K. Lipid entrapment and cellular changes in the rat myocard, lung and liver after long-term parenteral nutrition with lipid emulsion. A light microscopic and ultrastructural study. APMIS 1996;104(7-8):515-22.

15. Perez-Jaffe LA, Fufth EE, Minda JM, et al. Massive macrophage lipid accumulation presenting as hepatosplenomegaly and lymphadenopathy associated with long-term total parenteral nutrition therapy for short bowel syndrome. Hum Pathol 1998;29(6):651-5. doi: https://doi.org/10.1016/S0046-8177(98)80018-X

16. Ichai C, Quintard H, Orban JC, editors. Metabolic disorders and critically Ill patients: from pathophysiology to treatment. France, Paris: Springer International Publishing; c2018. Chapter 18, Nutritional Requirements in Intensive Care Unit; p. 401

17. Friedewald WT, Levy RI, Fredrickson DS. Estimation of the concentration of low-density lipoprotein cholesterol in plasma, without use of the preparative ultracentrifuge. Clin Chem. 1972;18(6):499-502. 
18. Grundy SM, Cleeman JI, Merz CN, et al. Implications of recent clinical trials for the National Cholesterol Education Program Adult Treatment Panel III guidelines. Circulation. 2004;110(2):227-39. doi: https://doi. org/10.1161/01.CIR.0000133317.49796.0E

19. Gerber ZRS, Zielinsky P. Fatores de risco de aterosclerose na infância: um estudo epidemiológico. Arq Bras Cardiol. 1997;69(4):231-6. http://dx.doi.org/10.1590/S0066782X1997001000002

20. Moura EC, Castro CM, Mellin AS, et al. Perfil lipídico em escolares de Campinas, SP, Brasil. Rev Saúde Pública. 2000;34(5):499-505. http://dx.doi.org/10.1590/S003489102000000500010

21. Lima SCVC, Arrais RF, Almeida MG, et al. Perfil lipídico e peroxidação de lipídeos no plasma em crianças e adolescentes com sobrepeso e obesidade. J Pediatr. 2004;80(1):23-8. doi: http://dx.doi.org/10.2223/ JPED.1129

22. Tchekmedyian NS, Halpert C, Ashley J, et al. Nutrition in advanced cancer: anorexia as an outcome variable and target of therapy. JPEN J Parenter Enteral Nutr. 1992;16(6 Suppl):88S-92S. doi: http://dx.doi. org/10.1177/014860719201600610

23. Ohnuma T, Paluri R, Adigun R. Cancer, Anorexia and Cachexia. [Internet]. Treasure Island, FL: StatPearls Publishing; 2019 [updated 2019 Aug 3; cited 2019, August 3. Available from: https://www.ncbi.nlm.nih. gov/books/NBK430977/

24. Laviano A, Meguid MM, Yang ZJ, et al. Cracking the riddle of cancer anorexia. Nutrition. 1996;12(10):706-10. doi: http://dx.doi.org/10.1016/S0899-9007(96)00164-5

25. Chwals WJ. Overfeeding the critically ill child: fact or fantasy? New Horiz. 1994;2(2):147-55.

26. Chioléro R, Revelly JP, Tappy L. Energy metabolism in sepsis and injury. Nutrition. 1997;13(9 Suppl):45S-51S. doi: http://dx.doi.org/10.1016/s0899-9007(97)00205-0

27. Klein CJ, Stanek GS, Wiles CE. Overfeeding macronutrients to critically ill adults: metabolic complications. J Am Diet Assoc. 1998;98(7):795-806. doi: http://dx.doi.org/10.1016/S0002-8223(98)00179-5

28. Cavaillon JM, Adib-Conquy M, Fitting C, et al. Cytokine cascade in sepsis. Scand J Infect Dis. 2003;35(9):535-44. doi: http://dx.doi.org/10.1080/00365540310015935

29. Herishanu Y, Polliack A, Shenhar-Tsarfaty S, et al. Increased serum C-reactive protein levels are associated with shorter survival and development of second cancers in chronic lymphocytic leukemia. Ann Med. 2017;49(1):75-82. doi: http://dx.doi.org/10.1080/078 53890.2016 .1232860

30. Favrot MC, Dellamonica C, Souillet G. Study of blood lipids in 30 children with a malignant hematological disease or carcinoma. Biomed Pharmacother. 1984;38(1):55-9.
31. Parsa N, Taravatmanesh S, Trevisan M. Is low cholesterol a risk factor for cancer mortality? Eur J Cancer Prev. 2018;27(6):570-6. doi: http://dx.doi.org/10.1097/ CEJ.0000000000000391

32. Alexopoulos CG, Blatsios B, Avgerinos A. Serum lipids and lipoprotein disorders in cancer patients. Cancer. 1987;60(12):3065-70. doi: 10.1002/1097-0142(19871215)60:12<3065:aidcncr2820601234>3.0.co;2-q

33. Rywik SL, Manolio TA, Pajak A, et al. Association of lipids and lipoprotein level with total mortality and mortality caused by cardiovascular and cancer diseases (Poland and United States collaborative study on cardiovascular epidemiology). Am J Cardiol. 1999;84(5):540-8. doi: http://dx.doi.org/10.1016/s0002-9149(99)00374-4

34. Naik PP, Ghadge MS, Raste AS. Lipid profile in leukemia and Hodgkin's disease. Indian J Clin Biochem. 2006;21(2):100-2. doi: http://dx.doi.org/10.1007/ BF02912921

35. Moschovi M, Trimis G, Apostolakou F, et al. Serum lipid alterations in acute lymphoblastic leukemia of childhood. J Pediatr Hematol Oncol. 2004;26(5):289-93. doi: http://dx.doi.org/10.1097/00043426-20040500000006

36. Ghalaut VS, Pahwa MB, Sunita, et al. Alteration in lipid profile in patients of chronic myeloid leukemia before and after chemotherapy. Clin Chim Acta. 2006;366(1-2):239-42. doi: http://dx.doi.org/10.1016/j. cca.2005.10.022

37. Muscaritoli M, Anker SD, Argile's J, et al. Consensus definition of sarcopenia, cachexia and pre-cachexia: joint document elaborated by Special Interest Groups (SIG) "cachexia-anorexia in chronic wasting diseases" and "nutrition in geriatrics'. Clin Nutr. 2010;29(2):154-9. doi: http://dx.doi.org/10.1016/j.clnu.2009.12.004

38. Fearon K, Strasser F, Anker SD, et al. Definition and classification of cancer cachexia: an international consensus. Lancet Oncol. 2011;12(5):489-95. doi: http://dx.doi.org/10.1016/S1470-2045(10)70218-7

39. Cederholm T, Barazzoni R, Austin P, et al. ESPEN guidelines on definitions and terminology of clinical nutrition. Clin. Nutr. 2017;36(1):49-64. https:/doi. org/10.1016/j.clnu.2016.09.004

40. Vaitkus JA, Celi FS. The role of adipose tissue in cancer-associated cachexia. Exp Biol Med (Maywood). 2017;242(5):473-81. doi: https://doi. org/10.1177/1535370216683282

41. Kinoshita A, Onoda $\mathrm{H}$, Imai N, et al. The C-reactive protein/albumin ratio, a novel inflammation-based prognostic score, predicts outcomes in patients with hepatocellular carcinoma. Ann Surg Oncol. 2015;22(3):803-10. doi: https://doi.org/10.1245/ s10434-014-4048-0 
Garófolo A, Maia-Lemos PS

42. Tsoli M, Robertson G. Cancer cachexia: malignant inflammation, tumorkines, and metabolic mayhem. Trends Endocrinol Metab. 2013;24(4):174-83. doi: https://doi.org/10.1016/j.tem.2012.10.006

43. Fournier M, Bonneil E, Garofalo C, et al. Altered proteome of high-density lipoproteins from paediatric acute lymphoblastic leukemia survivors. Sci Rep. 2019;9(1):4268. doi: https://doi.org/10.1038/s41598019-40906-x

Recebido em 27/9/2019 Aprovado em 18/11/2019 